\title{
The application of a reflective practitioner methodology by clerks to college governing bodies in England: reviewing the benefits for clerks, and also for college governors and college senior staff
}

\section{By Prof. Ron Hill (University of Stirling) and Joss Kang (touch consulting Itd)}

\begin{abstract}
This paper considers the application of a professional reflective journal to support the role of the clerk to the college governing body in England. Background detail regarding the role of the 'clerk to the corporation' in England is provided. The paper explains the basis for the formation of a reflective journal using a critical incident analysis methodology. The critical incident of most importance to clerks to college governing bodies is assumed to be the meeting of the governing body. The paper also provides a theoretical framework within which to locate this approach to the formation and application of a reflective journal. Two applied studies of the use of a reflective journal are described, including responses from participating clerks from their reflective experience. The paper concludes with a summary of the usefulness of this innovative approach to professional development for clerks to college governing bodies and explores some possible next steps in the application of this reflective methodology within leadership of colleges.
\end{abstract}

\section{Key Words}

clerk to the governing body, clerk to the corporation, further education, reflective journal, critical incident analysis

Introduction

The context for this paper is the governance and governing of further education colleges in England. There are currently $177^{1}$ general further education corporations, each with a governing body fulfilling the enacting of the 'further education corporation' with its responsibility for one or more colleges. Each further education corporation is technically a charity. This paper specifically concerns the post of 'clerk to the corporation' or more commonly expressed, 'clerk to the college governing body'. The clerk to the corporation is the governance and governing adviser to a further education corporation.

Further education corporations were permitted by the Further and Higher Education Act 1992 and, at the time, were funded and inspected by the Further Education Funding Council. In the Further Education Funding Council's (1996) 'A Guide for Clerks' the following statement provided the working assumption about the then new role of clerk to the corporation:

'To be effective, the clerk requires an appropriate measure of independence. The clerk needs to remain detached from discussions and decisions of the governing body and its committees, recording but not participating in them except where procedural issues arise'. (FENTO 1996, 3).

In 2001, the short-lived FENTO (Further Education National Training Organisation) produced 'standards' for clerks. Included with the details of the job description and how to fulfil the key tasks is advice on "how you might need to behave' as a clerk. Two of the five behaviours listed stand out as particular examples of the difficulties associated with being a clerk then .... and maybe now as well.

- You resist pressures from the governing body and the principal to achieve results by any means;

\footnotetext{
${ }^{1}$ Correspondence from Association of Colleges, 8 January 2019
} 
- You show courage and stamina under fire. You understand that the role of the clerk is not to be liked, and that sometimes people will react badly to being told what they can not do (FENTO 1996, 16)

In passing, one might wonder at the possibility of unintended consequences from the image of the model clerk portrayed by the expressions used by FENTO.

More recently in the governance of further education corporations, in 2013 the Learning and Skills Improvement Service published a report of a study into the condition of 'clerking'. The role of the governing body and the concomitant responsibilities of the clerk had evolved to be described as follows

'The clerk's role has never been more critical, following on from the commitment by the Coalition Government to free the sector so that it can respond directly to learner and employer need and be directly accountable for its delivery...... Clerking is at a 'tipping point' in terms of expectations of the role, and yet, paradoxically, there is evidence of pressures working against the clerk in some colleges'. (LSIS 2013, 5)

Six major themes were identified in this report as necessary to sustain effective clerking. These themes are (LSIS, 2013; 5)

○ The triumvirate working relationship between chair, clerk and principal

- The ability to maintain high standards of public life and to assess and scrutinise risk to the college

- Sufficient skills and salary to reflect the demands and senior role of clerking

- A recognition of the status and value of the clerk in colleges and the further education sector

- The clerk's capacity to fulfil their governance advisory role, including legal advice

- Sufficient training, support and continuing professional development, including professionalisation of the clerk through qualifications

These themes are helpful in portraying the nature of the role of the clerk to the corporation. Forrest et al (2018) followed the LSIS report with a national survey of clerks to college governing bodies in England supported by regional focus groups of clerks. The reported findings included two aspects of the role of clerk to the corporation which emphasised the importance of the role in contributing to 'the promotion of legitimate governance': managing communication on behalf of and to the governing body and acting as an influencer of others involved in college governance i.e. governors, senior staff, professional advisers. One quoted participant (Forrest et al; 2018, 168) 'likened the clerk's role to Virgil guiding senior managers and governors through the governing underworld'.

The Department for Education (DfE) issued a document in November 2018 titled 'Further education corporations and sixth form college corporations : governance guide' ${ }^{2}$. Within this document there is reference to the clerk as the 'governance professional'. Details are included in the footnote below.

2 Corporation clerks, also known as governance professionals, are critical to board performance.

You should ensure your board invests in your clerk's professional development and that there is an annual appraisal for the clerk, based on clear and measurable objectives to support and improve governance.

Your clerk should support boards in meeting high standards of governance and fulfilling legal or regulatory requirements. Your clerk should play an important role in communication between the board and executive managers.

Your clerk can provide guidance on:

- effective governance 
The clerk to the corporation is often compared in function to that of the company secretary in commercial and some charity settings. In MacNulty and Stewart's (2014) exploration of the role of the company secretary within the governance space (as an aspect of organisational space), they note three aspects of the role performed by the company secretary (op cit 2014,10), 'the humble clerk, the chair support, and the advocate for the collective conscience of the company'. MacNulty and Stewart believe this range of tasks reflects 'something of the variety, the layered and multidimensional possibilities of the company secretary role' in public corporations i.e. private companies. Following the findings of Forrest et al (2018), it would be appropriate to extend this description to that of the clerk to the corporation for a further education college.

Having intended to develop an awareness of the origins and evolving role of the clerk to the corporation, this paper now considers two projects which have used a reflective practitioner methodology to support and develop clerks in their role. In so doing this paper addresses a number of under-researched aspects of education including governance and governing practice of further education, and the role and performance of the clerk to the corporation ${ }^{3}$.

\section{Professional Learning Journal Formation}

The stimulus for critically reflective practice for the clerks to college governing bodies is the professional learning journal. Lee and Mills (2013) discuss the challenges and dilemmas of autoethnographic approaches to learning. A key point here is the use of the term 'journal'. A journal is considered to join 'accounts and reports of events with personal thoughts and reflections' (after Chabon and Lee-Wilkerson, 2006; cited by Lee and Mills 2013, 3). Importantly, such a process also enables journal keepers to include emotional aspects of their experience. The professional learning journal being formed and tested is therefore best considered as the clerk's 'reflective journal' throughout this paper.

Critics of autoethnographic approaches consider such personal activities may be prone to introspection and self-indulgence (Holt 2003). However, Lee and Mills usefully point out that it is actually the introspective nature of such methods that makes them valuable and therefore useful. Furthermore, the approach used in these reported studies provides a structure (based on the grid - see below) which channels critical thinking towards defined aspects of governing body meeting performance (predetermined by the clerk). Thus, the journal becomes one of structured introspection which hopefully overcomes methodological concerns.

A further point of concern has been raised by Hayman, Wilkes and Jackson (2012) about the time and effort it takes in maintaining a reflective journal. This is a legitimate concern faced by participants in the reported studies in this paper (see below). However, ways were devised to be time efficient and also the

- your obligations as a governor and your board's powers

- legal issues relating to governance

- the implications of policy or regulatory developments

- training and development opportunities for governors, underpinned by the clerk's regular skills audits of the board

- assessment of board performance

${ }^{3}$ From this point forward, for ease of reading, the role of clerk to the corporation will be referred to as 'clerk to the college governing body'. It should be noted that this term is shorthand for a range of situations extending from a governing body for one college to a governing body for a group of entities including one or more college brands and maybe a subsidiary company and/or other relevant organisations consistent with the purpose of the 'further education corporation'. 
demonstrable and continuing benefits seemed to outweigh any experienced feelings to conclude journal participation. Further details will be provided in the Two Studies section below.

As a foundation, the four principles of journal keeping (after Alaszewski 2006, reported in Bartlett \& Milligan 2015, 16) were adopted. Thus,

i. The reflective journal is defined by regularity; in this case, the regularity is shaped by the corporate meeting calendar. Typically, most college governing bodies meet at least six times per college year;

ii. The reflective journal is assumed to be private; the clerk can control the use to which his/her reflections lead to desired actions;

iii. The reflective journal is contemporaneous; in this case, the journal entry for the observed meeting is completed either during or shortly after the meeting event;

iv. The reflective journal is a time-structured record and is formed on a grid matrix of core governing behaviours and core governance requirements. The journal is supplemented by notes of personal reflections, thoughts, feelings, and experiences.

The foundation of the reflective journal is the application of critical incident analysis. Davies and Kinloch (2000) summarise critical incident analysis (CIA) as follows

'CIA has been developed as a tool for social work educators and learners to assist in the process of learning from current practice by reflecting on past experience and anticipating future action'. (Davies and Kinloch 2000, 137)

Davies and Kinloch elaborate by describing a critical incident by reference to Minghella and Benson 1995, 212) as 'a personal experience - snapshot, vignette, brief episode - which epitomises a situation or encounter of interest to the student .. from professional settings'. This paper extends the application of the 'critical incident' to governing board settings as an innovation in CIA use, a claim based on the summary of reported applications provided by Davies and Kinloch and a recent search of published research.

The use of college governing body meetings was ideal as the critical incident focus - all clerks could relate to the importance of the governing body meeting in their working lives and the use of a structure - the grid - helped to test understanding of what exactly was happening in the meeting in relation to the important aspects (as judged by the professional insight of the participating clerk to the college governing body).

Figure 1 shows the basic framework for the design of the reflective journal record. Journal keepers are required to select and establish key 'governing behaviours' and key 'governance requirements' for observation and review.

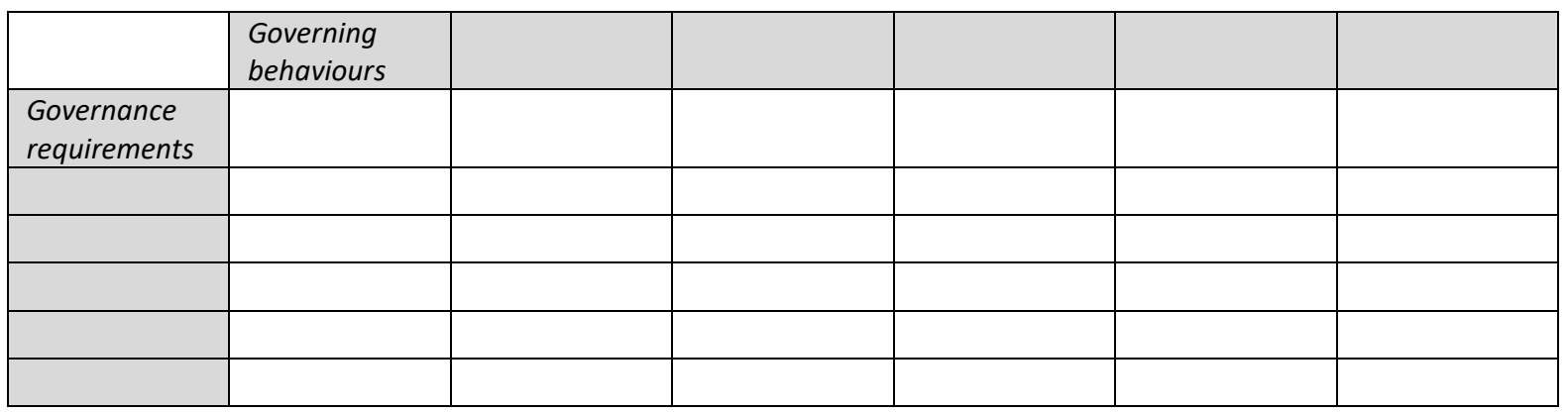

Figure 1: Basic Framework

Figure 2 shows examples of 'governing behaviours' and examples of 'governance requirements'. 


\begin{tabular}{|c|c|c|c|c|c|c|}
\hline & $\begin{array}{l}\text { Clear decision } \\
\text { making }\end{array}$ & $\begin{array}{l}\text { Insight and } \\
\text { engagement }\end{array}$ & $\begin{array}{l}\text { Pace and } \\
\text { ambition }\end{array}$ & Accountability & Risk focus & $\begin{array}{l}\text { Relations with } \\
\text { senior staff }\end{array}$ \\
\hline $\begin{array}{l}\begin{array}{l}\text { Board } \\
\text { strategy } \\
\text { [strategic } \\
\text { objectives] }\end{array} \\
\end{array}$ & & & & & & \\
\hline $\begin{array}{l}\text { Governance } \\
\text { code }\end{array}$ & & & & & & \\
\hline $\begin{array}{l}\text { Safeguarding } \\
\text { \& Prevent }\end{array}$ & & & & & & \\
\hline $\begin{array}{l}\text { Corporate } \\
\text { values }\end{array}$ & & & & & & \\
\hline Equality duty & & & & & & \\
\hline $\begin{array}{l}\text { English and } \\
\text { Maths }\end{array}$ & & & & & & \\
\hline
\end{tabular}

Figure 2: Example of Completed Grid Axes

The completion of the reflective journal framework for each governing body was a matter for the clerk to the college governing body. The options were either to complete each or selected cells in prose or to complete the grid in code with relevant details recorded in prose separately. The important point was to maintain a consistent approach to permit comparisons, trend data, and the development of expertise in journal entry. Participants were encouraged to supplement their grid with notes and commentary. This permitted background information, supporting evidence, and more of the emotional response to be recorded. Ciampa $(2017,3)$ stresses the value of the emotional reaction as well as well as keeping a record of the event as follows,

'Journal entries should provide not only a record of what happened but how we reacted emotionally; writing it down brings a certain clarity that puts things in perspective. In other cases, it's a form of mental rehearsal to prepare for particularly sensitive issues where there's no-one to talk with but yourself'.

Thus, the complete reflective journal for each clerk to the college governing body is a mix of

a. an assessment grid, designed to focus local priorities as well as core aspects of governing practice,

b. a personal narrative designed to help record the event and, in particular, the journal keeper's emotional response

c. an action response, following critical reflection which may have implications for the clerk only, or more widely.

\section{Theoretical framework}

This paper reports two studies of the application of a critically reflective practitioner process used by a sample of clerks to college governing bodies. This form of research activity is best referred to as 'close to practice' research. Wyse et al $(2018,14)$ define close to practice research as

research that focusses on aspects defined by practitioners as relevant to their practice, and often involves collaborative work between practitioners and researchers' $(2018,15)$.

The participating, critically reflecting, clerks (as practitioners) observed, reflected and acted upon on the performances of board meetings in their colleges. As Wyse et al (op cit) caution, closeness to practice can be seen as 'an epistemological weakness'. To acknowledge and address this concern, this study inevitably relies on the professional capacity of the participating clerks but also, crucially, involves the role of a mentor (unconnected to the college and its board) to aid reflective practice. 
There is insufficient space within this paper for a full discussion of critically reflective practice, but it is necessary to provide understanding of the approach used within this innovative methodology for the development of clerks to college governing bodies. This is an account of meta-cognition, that is the ability to think about our thought processes. Amass (2018) explains meta-cognition as being two processes firstly, knowing how we think and secondly, regulation of our thinking i.e. identifying and applying strategies to support our mental processes.

Thompson \& Thompson (2018) and Moon (2006) inform that reflective practice as part of professional development has developed for caring, health, and education professionals i.e. the 'helping professions' (Thompson \& Thompson, 2018, 3). It is an assumption of this paper that clerks to college governing bodies are also engagedin a capacity of helping i.e. influencing and enabling others such as governors, senior staff and stakeholders to be able to form a legitimate and confident governing process.

Schon $(1987,22)$ uses the term 'professional artistry' to refer to 'the kinds of competence practitioners sometimes display in unique, uncertain and conflicted situations of practice'. He believed that professional practice was more than rules and laws (positivism or technical rationality) and that the reality of professional practice could be the swampy lowlands which were messy, difficult and confusing (Thompson \& Thompson 2018,10). Assuming this picture of practice matches the professional role of the clerk to college governing bodies, the case becomes clear for the benefits of critically reflective practice. To pursue this case requires support for Schon's reflection-in-action, reflection-on-action and (after Thompson \& Thompson 2018, 11) reflection-for-action stages. In addition, although predominantly individualistic in focus, Schon recognised the importance of the organisation as well as the individual. Thus, as Thompson \& Thompson $(2018,13)$ state 'this means that promoting reflective practice will often involve seeking to influence the culture of the organisation in which we work in an attempt to make it more receptive to, and supportive of, reflective practice'.

A working assumption in the theoretical framework is 'critically reflective practice'. The deliberate use of 'critically' is to emphasise an approach which is 'characterised by questioning and not taking things for granted' (Thompson \& Thompson 2018, 21). To connect to the point above regarding organisational context, the approach adopted is more than atomism i.e. individualistic, and is summarised by Thompson \& Thompson $(2018,23)$ as 'a critically reflective practitioner is therefore someone who is not only selfaware, but also socially and politically aware - able to 'tune in' to the bigger social picture that plays such an important part in shaping people's lives, the problems they experience and the potential solutions to those problems'.

\section{Two studies applying the reflective journal methodology}

This paper reports on two reflective journal studies with clerks to college governing bodies in England. The first study, with three clerks to college governing bodies, operated from August 2016 until March 2017 (funded by touch consulting Itd). The second study (from August 2017 until March 2018), involved eight clerks to college governing bodies (plus a secretary to a higher education institution academic board and a company secretary to a school academy board). The second study was funded by the Education and Training Foundation and is summarised in an ETF report by Hill (2018). The British Educational Research Association 'Ethical Guidelines for Educational Research' were adopted and applied to both studies (BERA, 2018).

In both studies, mentor support was provided throughout the period of the study either on-line and/or via telephone contact. Mentors for the second study included the participants of the first study. It is important to note that mentoring support was cited in the interim and final evaluations by participating clerks as being of considerable benefit in forming the journal keeping process. Furthermore, once clerks began to experience and value the contribution of the journal keeping process, mentors acted in a more critical friend role, supporting critical incident reflections emerging from the grid and other records. 
Both studies demonstrated a range of benefits for the participating clerk to the college governing body. These benefits could be translated into benefits for the governing body and the achievement of its role and also benefits for college senior staff working to facilitate governing through report writing, in-college governor development etc.. In summary the benefits for clerks were evidenced as

- improved clarity regarding the practice of key governing processes

- improved clarity in developing and shaping the governing body agenda

- improved self-awareness and stronger professional identity

- improved relations with chair and principal

- experience and practice of using a relevant, personalised reflective tool

- embedding of personal critically reflective practice

- use of a methodology that creates and supports a considered change process

These benefits were drawn from the conversations with mentors during the project and summative evaluation (by questionnaire) of the professional journal as a critically reflective experience.

The following quotes from Study 1 encouraged the formation of Study 2.

Clerk 1 The journal is a big part my new thinking about how we address governing; the journal is a very useful method to view cultural change; it sharpened the big picture focus and helped with strategic thinking.

Clerk 2 The journal is a place where I'm seeing repeating patterns, a bigger landscape .... And this is leading to a better conversation with the Principal and Chair.

Clerk 3 Without the journal I would not have been so forward ..... it is part of how I do things

The following quotes from Study 2 reflect the tenor of the evidence of experience that was collected.

Clerk 5 Yes, I will continue with the journal approach; it really helps crystallise my thinking on what's required and how we're doing.

Clerk 6 Yes, I will continue with the journal process. We are all very keen and I can see it becoming part of my professional practice. .... I will be looking at the main board (grid) again as I am still thinking about the best thing to do with the columns (themes) content, but I'm fairly happy with the behaviours row.

Clerk 7 Yes, I will continue with the journal methodology. It is an integral part of shaping my board minutes, reflecting upon the work of the board, and future planning.

Clerk 9 My mentor was someone to be accountable to - ensuring I kept going. As someone who had been through the process my mentor was great at supporting my learning - encouraging me to relax with it and allow development to emerge rather than forcing the issue.

Clerk 5 I feel as though I'm having a lot more influence on the overarching work of the governing body and keeping them on track... I feel on top of things and able to provide informed and accurate advice.

Clerk 7 Key improvements: improved confidence, better focused agendas, improved quality of minutes as draft the minutes is an integrated practice with completing my journal and there is a nice feedback loop between the two.

Clerk 5 Surpassed expectations - it's clarified the importance of the clerk position for me. l'd like to encourage the chair and the principal to use the journal themselves to reflect. 
Clerk 12 I noticed use of the journal had drastically improved my observations of how meetings were operating, relationships, pinch points etc that I hadn't necessarily been as aware of prior to the starting the journal. I was more aware of the human element of the meetings rather than just process.

\section{Discussion}

The following questions merit discussion

a. How is the grid - a central element in the reflective journal - formed, completed and owned by the clerk?

b. What are the pitfalls to embedding this form of critically reflective practice?

c. Does the reflective process trialled by clerks have wider application e.g. to chairs, new governors?

d. How significant is the mentoring relationship in supporting the development and consolidation of critically reflective practice?

As figure 1 and figure 2 show above, the critical incident analysis grid is formed by governing behaviours on the horizontal axis and governance themes on the vertical axis. Thus, the cells created should reflect the assumed focus of the governing body. There is the opportunity to exercise professional choice in the formation of both axes, but there will be a considerable grid similarity given the role and responsibilities of a college governing body in England. The important point is that clerks have the flexibility to personalise their grid to ensure it has maximum relevance to the college governing body they are involved with.

The completion of the grid is also a matter of choice. There were three methods identified in Study $1-$ by exception, by complete oversight, by positive indicator. In reality these are not three completely different methods, it is more a matter of varying emphasis.

- In the 'by exception' model, the clerk completed cells in the grid of greatest concern to him/her. The brief text in the cells was backed up by a separate aid memoire of notes.

- The 'complete oversight' approach assumed every cell on the grid would be covered and reviewed.

- The 'positive indicator' approach showed a patchwork grid of positive entries - thus, by implication, empty cells required further consideration.

All three methods of grid completion 'worked' and enabled clerks to reflect and then pursue aspects of governing practice. Of critical importance was the pattern of grids over time e.g. through a college year. This pattern, unachievable in any other way, permitted the clerk to both identify a problem and to consider responses to the problem over time.

The pitfalls of this form of critically reflective practice seem to be (i) time (ii) simplification (iii) mentor dependency (iv) professional vision. As with all reflective practices, time is required. Feedback from Study participants has suggested that the additional time, together with a relevant, personalised reflective process has been worthwhile. No feedback was received which said - too time consuming, not worth the effort.

There is a danger of simplification if the focus, by the clerk, on the performance of the college governing body is assumed to be the totality of the role of the clerk. The clerk's role extends across the 'governance space' (McNulty and Stewart 2014, 2) and, whilst meetings of the governing body are very valuable, the clerk's role is wider and bigger. However, so many aspects of the shape and practice within the governance space coalesce around the boardroom and the governing body either directly or indirectly e.g. via a committee or working group. A claim of simplification might also be raised regarding the distillation of the boardroom to a grid of behaviours and governance themes. In response, the grid formation can be basic or advanced, according the professional confidence and vision of the clerk. In whatever form the grid is framed, the grid can perform a role as a stimulus to encourage reflection of 
what was the governing body actually doing at the meeting under consideration. A sequence of records of governing body meetings as critical incidents can provide a new pattern for reflection enabling a look at the governing body through a timeframe e.g. an annual cycle of business.

Participating clerks in both studies suggested wider application of the grid as a part of a critically reflective practice associated with governing colleges. Clerks believed there was potential benefit for governors generally; specific groups of governors such as chairs, student governors, staff governors, new governors; senior college staff - who have a key role in supporting and enabling effective governance. The suggestion of senior staff benefitting from this methodology is particularly interesting considering one of the recommendations from Hill and James' (2014) study of the contribution of senior managers to further education governance:

'governing bodies should ensure that every member of the senior staff is trained and supported in the foundations of college governance and governing'

No development of these possible wider applications has taken place to date.

\section{Conclusion and next steps}

To begin to appreciate the impact of the reported methodology to achieve a valued critically reflective practice for clerks to college governing bodies, it is useful to refer to the work of Hill and James (2017) and sense the importance of clerks through the reported words of chairs of college governing bodies. The following four quotes are examples of a wider series of supportive and appreciative comments (2017, 69):

'The clerk is a hugely important and influential role'

'There is high value provided by the clerk, who I think of as the company secretary'

The clerk is absolutely pivotal to the success of the chair and therefore the success of the college' 'She's vital!'

But Forrest et al $(2018,170)$ reported that some clerks involved in their extensive study did not feel 'fully authorised to promote legitimate governance'. There were issues of status and authority, working time and remuneration, gendered relations (female clerk/male chair), limited administrative support and lack of development opportunities.

The approach to critically reflective practice for clerks reported in this paper has attempted to build on the model role of the clerk and our study evidence has shown that participants gained more confidence, more personal energy, and clearer thinking about their contribution to the effective governing of their further education college. Specifically, after Moon's 'uses of learning journals' (2006, 44-51), the evidence from the reported studies with clerks to college governing bodies (presented in this paper) suggests it is reasonable to make the following claims that the reflective journal has :-

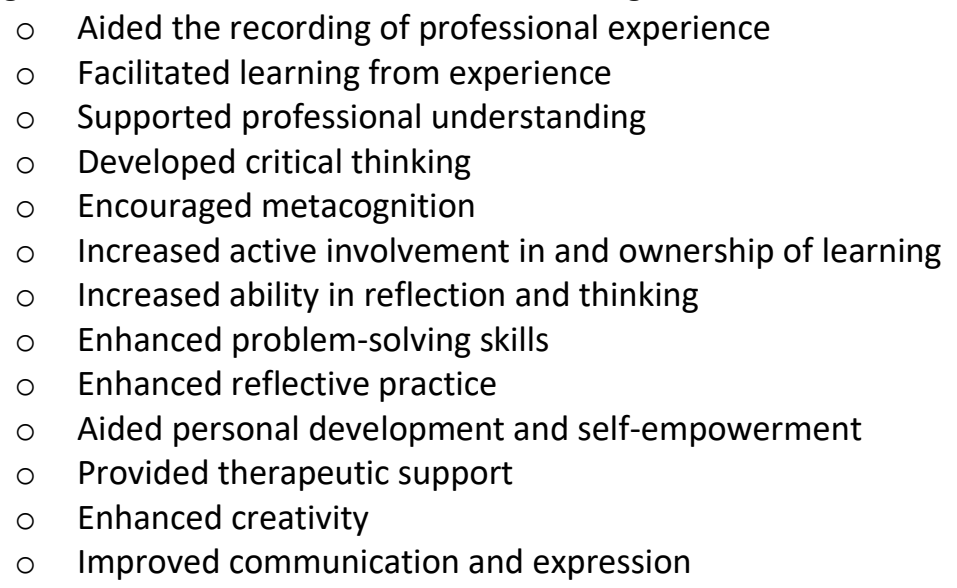


These gains for the clerk to the college governing body are located within a college 'governance space' (after McNulty and Stewart 2014, 2) shared with (a) governors i.e. members of the college governing body and (b) senior staff, who support and facilitate the reporting requirements of governing colleges.

A further trial of this reflective methodology is currently underway during 2018/19 (funded by Scotland's College Development Network) with a sample of secretaries to college governing bodies in Scotland. The outcome from this study will be reported in due course. Furthermore, consideration is being given to extending the application of reflective journal keeping based on critical incident methodology to clerks to school and academy governing bodies in England and also to company secretaries and their equivalent in governing board settings beyond the education sector.

\section{Funded by}

The authors would like to thank

- the Education and Training Foundation for its funding of Study 2;

- the College Development Network (Scotland) for funding and supporting what will be known as Study 3.

\section{Thanks}

The authors would like to thank

- Chris Jones, Jennifer Foote and Craig Williams for their commentary on earlier versions of this paper;

- $\quad$ the participating clerks and their respective college governing bodies;

- $\quad$ mentors to participating clerks in the reported studies

\section{References}

Alaszewski, A. 2006 Using diaries for social research. London: Sage Publications

Amass, H. 2018 Have we forgotten to teach pupils how to learn? TES Scotland, 27 April 2018

Bartlett \& Milligan 2015 What is diary method? Bloomsbury, London, U.K.

British Educational Research Association 2018 Ethical Guidelines for Educational Research Fourth Edition 2018 London, U.K.

Chabon, S.S. and Lee-Wilkerson, D. 2006 The use of journal writing in the assessment of CSD students' learning about diversity: a method worthy of reflection Communication Disorders Quarterly 27(3) 146158

Ciampa, 2017 The more senior your job title, the more you need to keep a journal Harvard Business Review May 2017

Davies, H. and Kinloch, H. 2000 Critical Incident Analysis : Facilitating reflection and transfer of learning in Transfer of Learning in Professional and Vocational Education eds. Cree, V. \& Macaulay, C. (2000) Routledge, London, U.K.

FENTO 2001 Governors and Clerks in Further Education : Benchmark Standards FENTO, London, U.K.

Forrest, C., Goodall, J., Hill, R., and James, C. 2018 The role of the clerk to the corporation in promoting the legitimate governance of further education and sixth form colleges in England : a role for the governance of all educational institutions? Journal of EMAL Vol 46 No 1 January 2018 
Further Education Funding Council 1996 A Guide for Clerks HMSO, London, U.K.

Hayman, B., Wilkes, L. and Jackson, D. 2012 Journaling : Identification of challenges and reflection on strategies Nurse Researcher 19(3) $27-31$

Hill, R. 2018 Sharpening your focus on governing practice: final report Education and Training Foundation, London, U.K.

Hill, R. and James, I. 2013 Appreciating the contribution of senior managers to further education college governance in England Management in Education DOI : 10.1177/0892020613492683

Hill, R. and James, C. 2017 An analysis of the role and responsibilities of chairs of further education college and sixth form college governing bodies in England Journal of EMAL, Vol 45(1) 57-76

Holt, N.L. 2003 Representation, legitimation and autoethnography : An autoethnographic writing story International Journal of Qualitative Methods 2(1) 18 - 28

Learning and Skills Improvement Service 2013 Clerking in the new era: implications for college governance (Full Report) LSIS, London

Lee, A. and Mills, S. 2013 Is anybody listening, does anybody care? The value of reflective journals as a source of qualitative data Paper presented to the British Academy of Management 2013

MacNulty and Stewart 2014 Developing the governance space : a study of the role and potential of the company secretary in and around the board of directors Organisation Studies 20141 - 23

Minghella, E. and Benson, A. 1995 Developing reflective practice in mental health nursing through critical incident analysis Journal of Advanced Nursing $21205-13$

Moon, J.A. 2006 Learning Journals : A Handbook for Reflective Practice and Professional Development Routledge, Abingdon, Oxon, U.K.

Schon, D. 1987 Educating the Reflective Practitioner Jossey-Bass, San Francisco, U.S.

Thompson, S. \& Thompson, N. 2018 The Critically Reflective Practitioner Palgrave, London, U.K.

Wyse, D., Brown, C., Oliver, S., and Poblete, X. 2018 The BERA Close to Practice Research Project, reported in Research Intelligence, pub. British Educational Research Association, Issue 137, Autumn 2018 